\title{
Environmental studies in connection with mining activity in Greenland
}

\begin{abstract}
Gert Asmund
Abstract

The Geological Survey of Greenland monitors the environment around mining sites in Greenland. At the lead-zinc mine Black Angel at Mârmorilik, tailings are disposed directly into the sea and this results in considerable dissolution of zinc, cadmium and especially lead. At Ivigtut, where cryolite was formerly mined, dispersion of lead into the marine environment has been observed, and at the depleted lead-zinc mine at Mestersvig severe metal dispersion from a land-based tailing deposit has been demonstrated.
\end{abstract}

\section{Introduction}

Environmental surveys by the Geological Survey of Greenland (GGU) started in 1972 in connection with the establishment of the lead-zinc mine at Mârmorilik in West Greenland. At that time it was evident that the authorities had to control not only the mining of the ore but also the environmental consequences of such mining. The principal reasons were put forward by the Director of the Geological Survey of Greenland to the Ministry for Greenland in 1972, in the following words (translated from Danish):

\begin{abstract}
'The study of the environmental impact of ore production, including an assessment of the biotic tolerance, monitoring of the recipient and the environmental background, demands knowledge of biology, toxicology, geochemistry, metallurgical chemistry and hydrology. The three last mentioned disciplines are related to the activities of the Geological Survey of Greenland in a natural way, as the Survey has sufficiently advanced chemical laboratories and expertise to interpret the environmental data acquired in this respect.'
\end{abstract}

On this basis environmental monitoring in Greenland was initiated with the mining activity at Mârmorilik; further studies were made around the cryolite mine at Ivigtut in South Greenland and the depleted lead mine at Mestersvig in East Greenland.

\section{Mârmorilik}

To determine the natural background around the mine, sampling and analysis of bottom sediments, sea-water, mussels (Mytilus edulis) and seaweed (Fucus vesiculosus and Fucus disticus), the epifauna and fish fauna, were carried out during the summers of 1972 and 1973 in cooperation with the Water Quality Institute of Denmark, the Greenland Fisheries Investigations and the Institute of Petrology of the University of Copenhagen.

In February 1974 the first environmental monitoring after the opening of the mine was initiated, mainly to confirm the current contention that the tailings discharged into the fjord of Agfardlikavsâ (fig. 1) since the autumn of 1973 were not harmful to the marine environment as concluded from laboratory experiments carried out by the mining company. The results of this survey (Table 1) came as a surprise, the dissolved metal content in Agfardlikavsâ being 


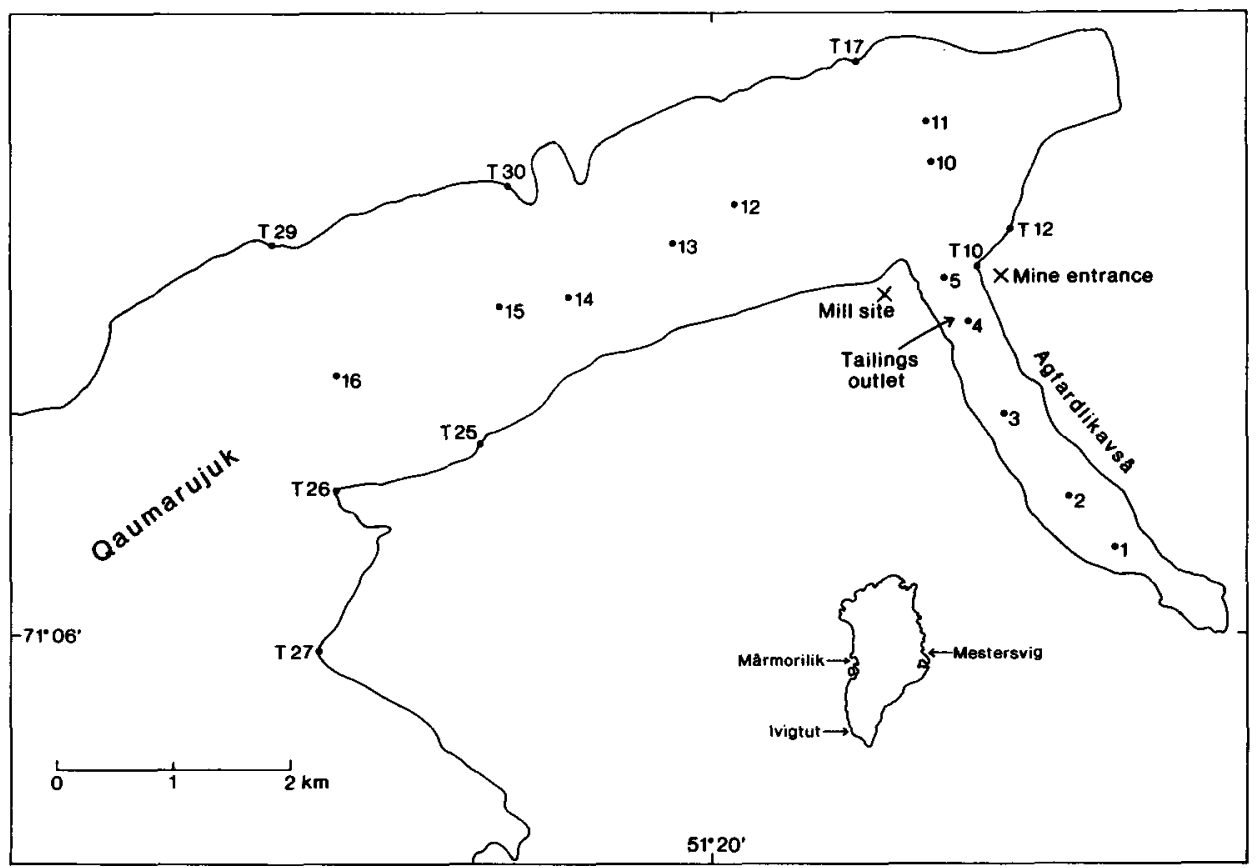

Fig. 1. Map of the sampling localities in the Mârmorilik area. Numbers indicate the localities where water and sediment samples were collected. Seaweed and mussels were collected at the localities marked T.

much higher than expected. These chemical analyses were confirmed by other laboratories and it soon became evident that this metal dissolution in sea-water and subsequent contamination of the environment was a severe case of pollution in Greenland.

During the autumn of 1974 the research vessel Adolf Jensen was sent to Mârmorilik, and samples of water, sediment, commercial catches, seaweed, mussels and benthos were collected. Subsequent environmental monitoring has since been carried out twice a year, usually from Adolf Jensen in August-September and from the ice in February, March or April. The results are described in a series of reports called Recipientunders $\phi g e l s e r$ of which eight have so far been published (GGU et al., 1973-1979, 1980, 1982).

Table 1. Dissolved zinc, cadmium and lead ( $\mu g / l)$ in Agfardlikavsâ, February 1974, compared to reference values of 1973

\begin{tabular}{lrrc}
\hline & Zn & Cd & Pb \\
\hline February 1974 & 422 & 2.4 & 200 \\
Reference value 1973 & 4 & $<0.4$ & 1.5 \\
\hline
\end{tabular}


Ivigtut

In 1982, when the mining company Kryolitselskabet $\emptyset$ resund A/S planned to resume mining of cryolite at Ivigtut and empty the open pit for water, the Survey took part in an environmental survey in Arsuk Fjord in June and November of that year and in June 1983. The results of this study (Hansen \& Asmund, 1983) show that from Ivigtut, too, there has been lead contamination of the marine environment. As far as living matter is concerned, only mussels and seaweed have been found to be polluted. Increased lead contents have also been found in water and sediment samples. Sediment cores show that the pollution increased steadily from about 1930 and was at a maximum in the mid-70s; since then it has decreased (Bondam \& Asmund, 1986).

\section{Mestersvig}

One of the results of studies in East Greenland around the depleted lead-zinc mine at Blyklippen near Mestersvig was the demonstration of the adverse effects of the tailings disposed. The tailings were deposited on land and are now being gradually washed out by meltwater down the slope into the river Tunnelelv, leading to increased levels of lead, cadmium, and especially zinc in the river water and, as a consequence, in seaweed along the coast of Kong Oscar Fjord close to the Mestersvig airstrip.

The scope of future environmental studies by the Survey will, to a large extent, depend on the industrial development in Greenland. At present, mining is the industry most likely to create environmental problems.

Some results of GGU's investigations from Mârmorilik and Ivigtut are described in more detail below.

\section{Marine studies at Mârmorilik}

The heavy metal content of the sea-water at Mârmorilik is determined by anodic stripping voltametry, whereby the metal ions in solutions are precipitated electrolytically on an electrode of mercury. After precipitation the potential of the mercury electrode is linearly changed towards a positive potential, and the metal ions are successively redissolved in the order $\mathrm{Zn}, \mathrm{Cd}, \mathrm{Pb}$ and $\mathrm{Cu}$. The process of redissolution is marked by a peak in the electric current flowing through the electrode. The peak is proportional to the concentration of the metal in the sample. This method is very sensitive, with a detection limit in the $\mathrm{ng} / \mathrm{l}$ range for the above-mentioned metal ions, dissolved in water.

The flotation plant discharges about 450000 tons of tailings into the fjord Agfardlikavsâ each year where they mostly settle within a radius of $1 \mathrm{~km}$ from the outlet point (fig. 1 ). The bottom $30 \mathrm{~m}$ of sea-water in the fjord is enriched throughout the year in dissolved heavy metals because the tailings contain soluble heavy metal compounds, probably carbonates. Due to physical conditions, the dissolved heavy metals content of the fjord waters is stratified during the summer and autumn as is exemplified in Table 2. In the winter and spring when the fjord is covered by ice and there is negligible influx of fresh melt-water into the fjord, the salinity, temperature and dissolved heavy metal content are normally constant with depth, i.e. there occurs an homogenisation under the ice cover. At the same seasonal periods as there is homogenisation of the waters in Agfardlikavsâ the upper 10-20 m of the 
Table 2. Examples of depth distribution of metals dissolved in sea-water $(\mu \mathrm{g} / \mathrm{l})$ in Agfardlikavsâ and Qaumarujuk

\begin{tabular}{llllllll}
\hline $\begin{array}{l}\text { Depth } \\
\mathrm{m}\end{array}$ & $\mathrm{Zn}$ & $\mathrm{Cd}$ & $\mathrm{Pb}$ & $\mathrm{Zn}$ & $\mathrm{Cd}$ & $\mathrm{Pb}$ \\
\hline
\end{tabular}

Agfardlikavsâ (average of 2 localities, $1 \& 4$ ) October 1979

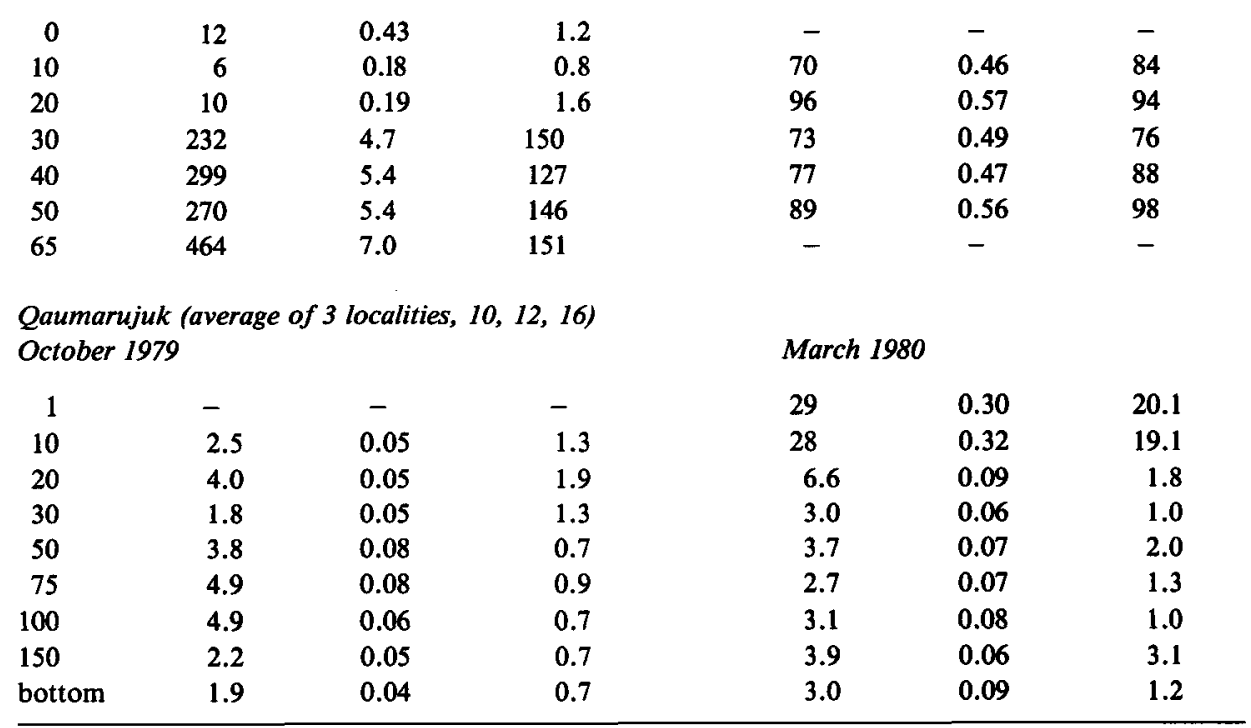

waters of the outer fjord, Qaumarujuk are enriched in heavy metals (Table 2). Such a distribution pattern of the dissolved heavy metals in the two fjords is explained by the topography of the fjords and the mixing conditions during the seasonal variations.

The two fjords are separated by a threshold across the mouth of Agfardlikavsâ at a depth of $25 \mathrm{~m}$. This threshold is the main cause of the adverse situation as to dissolved heavy metal content in the two separate fjords. This was recognised in 1978 after monitoring oceanographic parameters throughout most of a year (Lewis \& Perkin, 1982). Subsequently a more comprehensive study of the hydrological conditions in the fjord system was carried out (Møller, 1984).

The following picture of the processes taking place has emerged from these studies.

In the summer and autumn the denser, metal-bearing water remains below the level of the threshold while fresh melt-water with lower density discharged into the fjord at the rate of $\mathbf{8 0}$ million cubic metres a year causés stratification in the water of Agfardlikavsâ (fig. 2a). In winter and spring the surface of the fjord is frozen with an approximately $80 \mathrm{~cm}$ layer of ice and there is no influx of fresh-water. The freezing of sea-water is accompanied by emission of salt into the underlying water with consequent increase in salinity and density of the water immediately under the ice. This situation is unstable and the waters gradually homogenise (fig. 2b). Thus metal-bearing water in Agfardlikavsâ is mixed throughout the fjord depth 


\section{Qaumarujuk}

Agfardlikavsâ

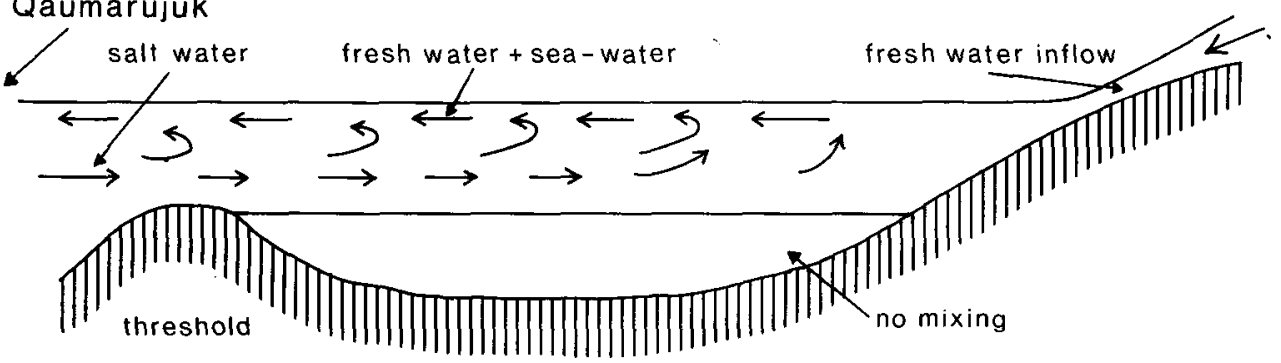

a

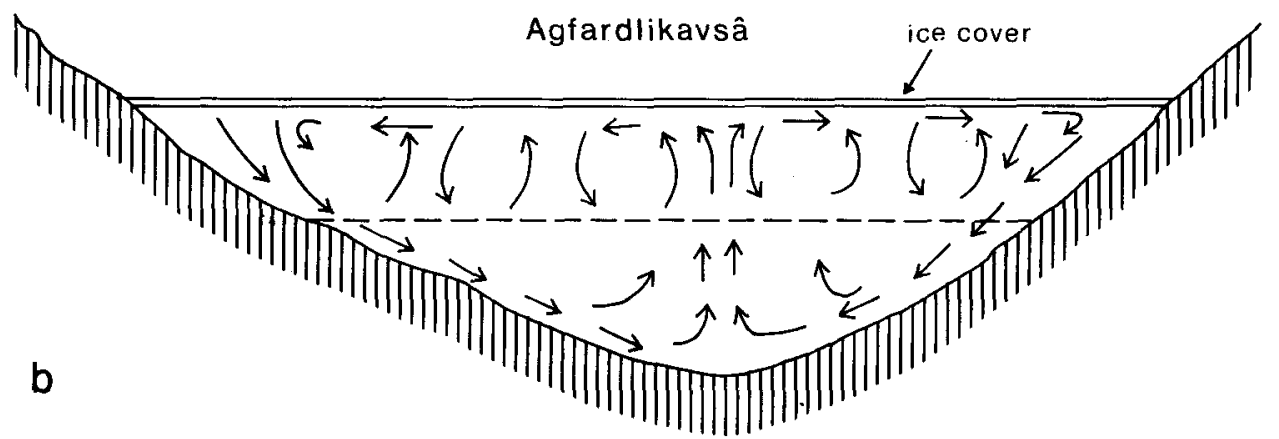

Fig. 2. Schematic diagram showing the mixing conditions of the water in Agfardlikavsâ; a: summer conditions, $\mathbf{b}$ : winter conditions showing mixing conditions under an ice cover.

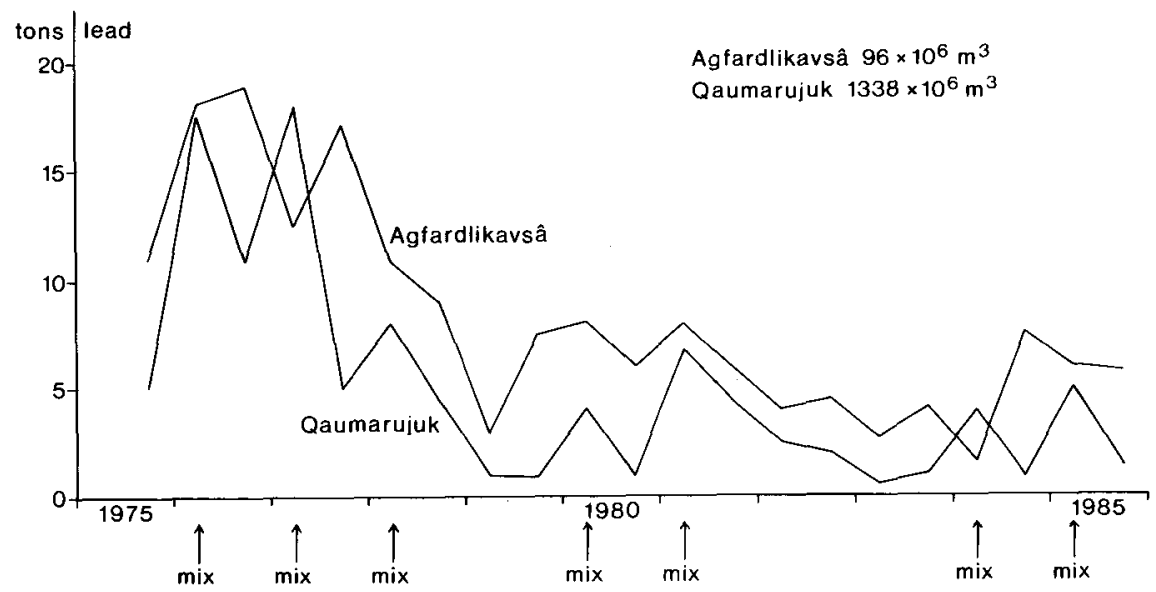

Fig. 3. Variation in dissolved lead in the waters of Qaumarujuk and Agfardlikavsâ from 1975 to 1985.

'Mix' marks the seasons where there has been total mixing of the water in Agfardlikavsâ. 
and can be carried by tidal and other currents out of the fjord into Qaumarujuk. This explains the higher contents of heavy metals in the upper water layers of Qaumarujuk in the winter and spring.

The homogenisation of the waters in Agfardlikavsâ does not take place every year. In the years 1979, 1982 and 1983 homogenisation did not take place. Møller (1984) showed that this coincides with years when the salinity of the waters of Qaumarujuk just below the height of the threshold never exceeded the salinity of the bottom waters of Agfardlikavsâ. In other years when a dense water layer in the winter and spring reaches the upper regime of Qaumarujuk, an influx of this layer past the threshold into Agfardlikavsâ occurs, resulting in further mixing of the water in Agfardlikavsâ. The mixing usually takes place in the early spring. However, since the difference in salinity of sea-water in Qaumarujuk relative to the salinity in Agfardlikavsâ controls this mixing process, it takes place irregularly. The seasons in which complete mixing of the water in Agfardlikavsâ has taken place are marked with arrows in fig. 3 , in which the calculated total dissolved lead content in the two fjords has been illustrated for the time period 1975 to 1985.

\section{The heavy metal content in sea-water at Mârmorilik from 1975 to 1985}

The large number of sea-water analyses carried out over the years can be illustrated in a few figures expressing the calculated total amount of dissolved metal present in the fjords Agfardlikavsâ and Qaumarujuk from 1975 to 1985 (Asmund \& Glahn, 1985). Lead is of special interest since it poses the gravest contamination risks. The highest content of dissolved lead was observed in the spring of 1976 when 18.3 tons was present in Agfardlikavsâ and 17.4 tons in Qaumarujuk (fig. 3). Subsequently the total content of dissolved lead decreased and was particularly low in the spring of 1979 . There was again a rise until the spring of 1981, followed by a gradual decrease with a total of 3.4 tons for the two fjords in April 1983, the lowest figure so far.

The decrease in total dissolved lead content is due to various pollution abatements exercised by the mining company since 1978 , especially the treatment of the tailings with slaked lime and aluminium sulphate.

\section{Bottom sediments in Qaumarujuk and Agfardlikavsâ}

The recent bottom sediments in the fjords around Mârmorilik are rich in carbonates derived from the surrounding limestone formation. On average the carbonate content of the sediments in Agfardlikavsâ calculated as $\mathrm{CaCO}_{3}$ is $76 \%$ and that for Qaumarujuk is $24 \%$. Where this fjord merges with the outer fjord system, the $\mathrm{CaCO}_{3}$ content of the bottom sediments is still $18 \%$.

The content of trace elements, including heavy metals, is closely related to the distribution of these elements in the surrounding rocks (Bondam, 1978). Following the start of discharge of tailings from the flotation plant, the content of heavy metals in the upper sediments increased throughout Agfardlikavsâ, as expected. Close to the outlet point the heavy metal content of the topmost sediment layer is comparable to that of the tailings discharged into the fjord. The heavy metal content of the topmost layer increases away from the discharge point up to about 0.5 to $1.5 \mathrm{~km}$ due to the very fine-grained and metal-rich particles from the tailings being transported a longer distance before settling. 


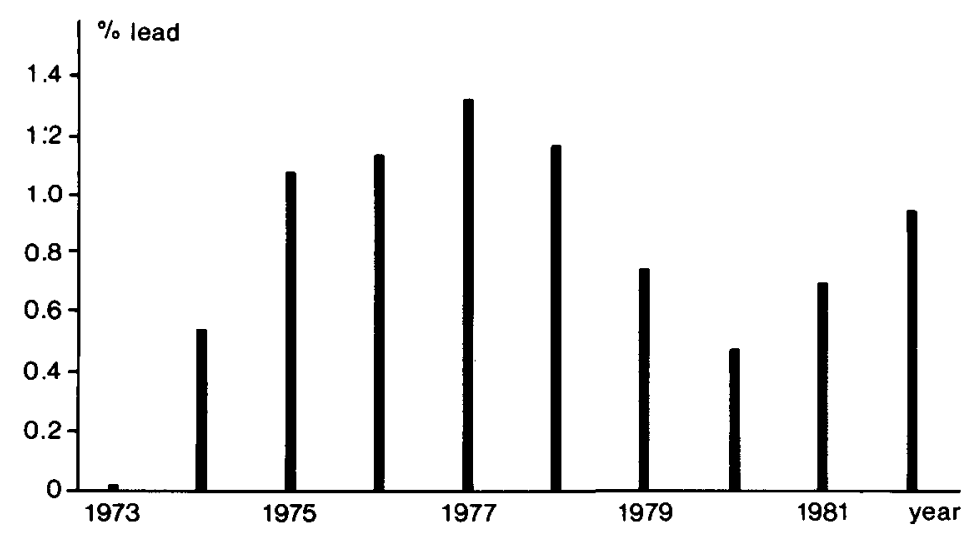

Fig. 4. Variation in lead content of the upper layers of bottom sediments in Agfardlikavsâ from 1975 to 1982 at about $800 \mathrm{~m}$ from the discharge point of the flotation plant.

In the remaining part of Agfardlikavsâ the top layer consists of natural silt, carried into the fjord by a meltwater stream from the Inland Ice, mixed with $10-30 \%$ of the fine-grained fraction of the tailings. Fig. 4 shows the variation over the years of the lead content in the upper layer about $800 \mathrm{~m}$ from the outlet point where the fine-grained part of the tailings accumulates.

The sediment samples from 1980 had the lowest lead content so far recorded, which agrees with a mimimum contamination of sea-water in 1979 (fig. 3) probably due to a very low size fraction of fine-grained lead-bearing particles in the tailings discharged during 1979. Studies made by the mining company have shown that there is a close correlation between particle size and content of lead compounds (K. Pedersen, personal communication).

\section{Bottom sediments in Arsuk Fjord}

An environmental study was carried out in the area around Arsuk Fjord adjacent to the cryolite open pit mine at Ivigtut. Analyses of mussels collected along stretches of coast in the neighbourhood of the open pit showed lead contents far in excess of $10 \mathrm{mg} / \mathrm{kg}$ dry weight (fig. 5), which is the WHO maximum limit for human consumption. In the immediate vicinity of Ivigtut, lead levels between 430 and $700 \mathrm{mg} / \mathrm{kg}$ were observed (Hansen \& Asmund, 1983).

The bottom sediments of Arsuk Fjord give a record of lead dispersion. Samples were taken at eight localities. The cores of sediment, up to $25 \mathrm{~cm}$ long, were sliced into segments of $1 \mathrm{~cm}$. The content of total lead and lead soluble in a $25 \%$ acetic acid solution was determined. Acetic acid treatment dissolves lead in colloidal form or lead adsorbed on grain particles, present in carbonates and amorphous oxides of iron and manganese, or loosely bound to organic material. It is this fraction of the total lead content that is biologically available and thus constitutes a threat for the biota when available in excess.

The age of deposition of the successive sediment samples was measured by the determination of the content of the natural ${ }^{210} \mathrm{~Pb}$ isotope in the sediments by a method developed by Häsänen (1977). The results of these age determinations, carried out by Madsen (1983), are 


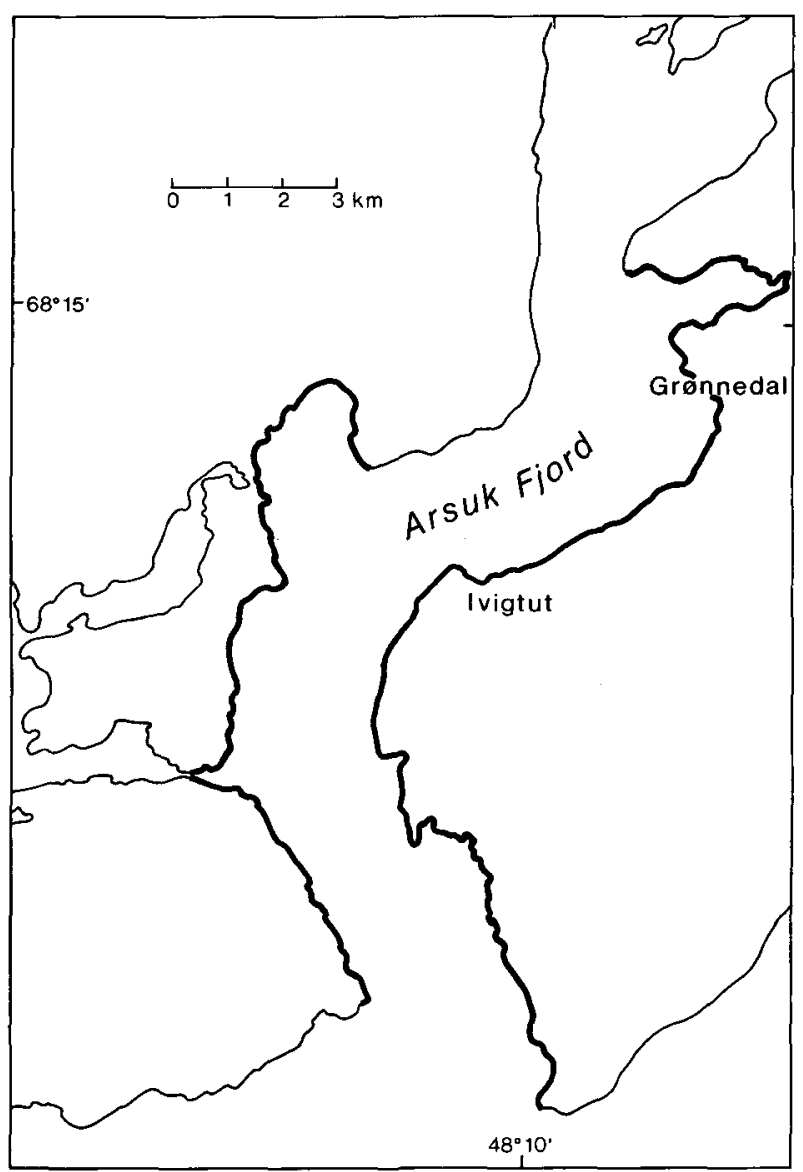

Fig. 5. Map of Arsuk Fjord. Mussels collected along the stretches of coast shown by heavy lines contain lead levels higher than $10 \mathrm{ppm}$.

shown in fig. 6 for a sediment core $800 \mathrm{~m}$ from Ivigtut, together with the content of total lead and lead soluble in acetic acid.

It appears that sediments deposited before the end of last century had a total lead content of about $33 \mathrm{ppm}$. Later sediments show gradually higher lead concentrations, reaching a peak in the early 1970s. The increase in the total lead content is paralleled by an increase in the content of acetic acid soluble lead, while the amount of detrital lead is constant. The conclusion can be drawn that the present contamination of the bottom sediments of Arsuk Fjord started in the mid-1930s and culminated in the 1970s. Since the increase in this case is due to lead available to the biota it may be concluded that lead dissolved in sea-water was precipitated and most probably adsorbed on the particle surfaces of the sediment grains (Bondam \& Asmund, 1986). 


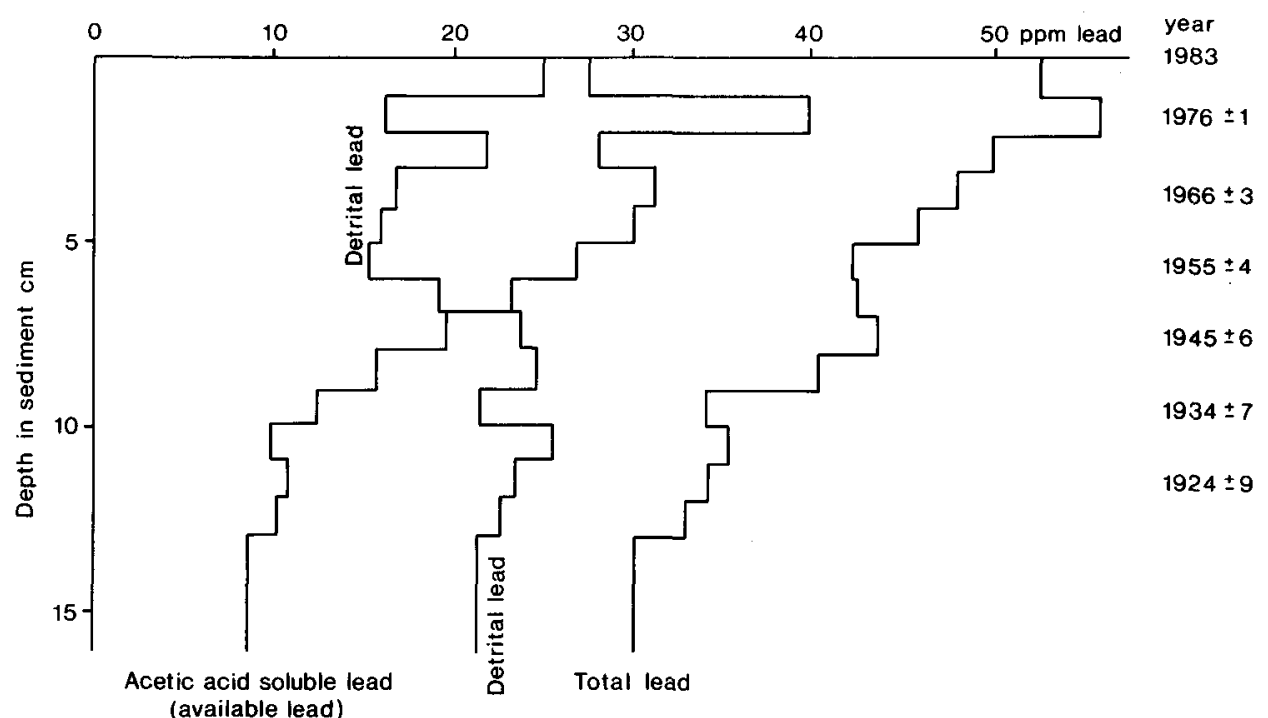

Fig. 6. Total lead and acetic acid soluble lead in the sediment core (No. 1) from Arsuk Fjord $800 \mathrm{~m}$ from the open pit mine. Age of sediments from ${ }^{20} \mathrm{~Pb}$ analysis.

\section{Dust dispersal}

The lichen Cetraria nivalis is a good indicator of dust dispersal because it solely absorbs nourishment from the air and from fall-out and rain on the plant. Its heavy metal content is therefore proportional to the fall-out of heavy metal at the habitat.

Table 3 indicates that the degree of airborne lead over Ivigtut is no higher than that over Nûk/Godthåb where lead in the atmosphere is presumed to derive entirely from human activity (Asmund \& Bondam, 1984). In contrast, the airborne dispersal of lead at the active mining and milling plant at Mârmorilik is considerably higher (Pilegaard, 1983).

Table 3. Lead contents in the lichen Cetraria nivalis $(\mathrm{mg} / \mathrm{kg})$

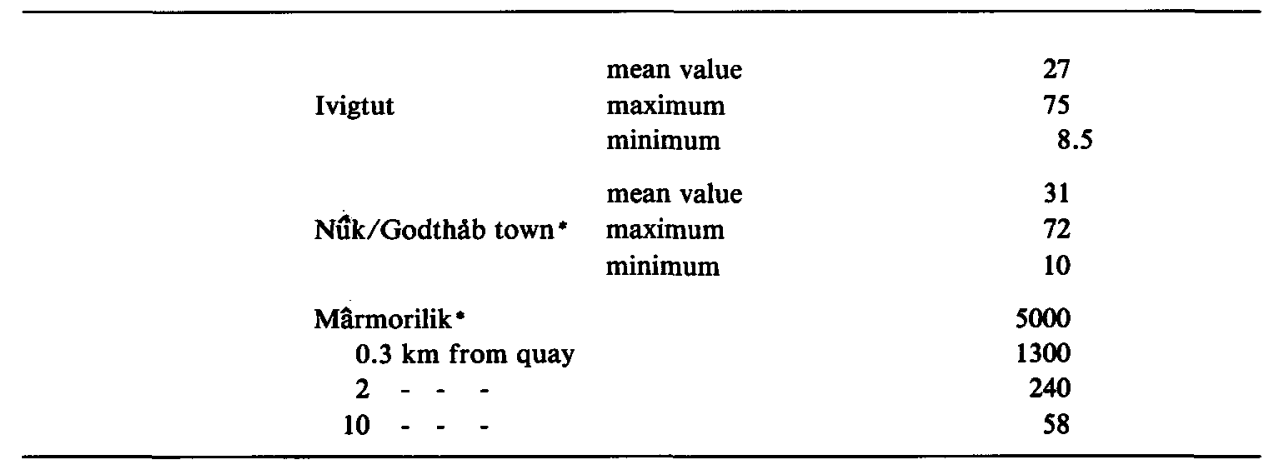

* from Pilegaard (1983). 


\section{References}

Asmund, G. \& Bondam, J. 1984: Undersøgelser af lav Cetraria nivalis from Ivigtut-området for bly. Unpublished internal report, $9 \mathrm{pp}$.

Asmund, G. \& Glahn, J. 1985: Miljøundersøgelser ved Maarmorilik, havvandsunders $ø$ gelser, marts 1985. Opløste tungmetaller 1975-1985. Unpublished internal report, $12 \mathrm{pp}$.

Asmund G. \& Møller, J. S. 1985: Long term variations governing the spreading of dissolved metals from mine tailings discharged into an arctic sill fjord. Abstr. 8th international Conference on Port and Ocean Engineering under Arctic Conditions (POAC), Narssarssuaq, September 1985, 207-219.

Bondam, J. 1978: Recent bottom sediments in Agfardlikavsâ and Qaumarujuk fjords near Mârmorilik, West Greenland. Bull. geol. Soc. Denmark 27, Spec. Iss. 39-45.

Bondam, J. \& Asmund, G. 1986: Blyspredning i Arsuk Fjord. En unders $ø$ gelse af bundaflejringerne. Unpublished internal report, $28 \mathrm{pp}$.

GGU et al. 1973-1979: Recipientundersøgelse, 1972, 1973, 1974, 1975/76, 1976/77, 1977/78, Agfardlikavsâ, Qaumarujuk. Copenhagen: Grønlands Geologiske Undersøgelse.

GGU et al. 1980, 1982: Recipientundersøgelse ved Mârmorilik 1978/79, 1979/80. Copenhagen: Grønlands Geologiske Undersøgelse.

Hansen, M. M. \& Asmund, G. 1983: Miljøundersøgelser ved Ivigtut 1982. Copenhagen: Grønlands Fiskeriundersøgelser, Grønlands Geologiske Unders $\emptyset$ gelse, $47 \mathrm{pp}$.

Häsänen, E. 1977: Dating of sediments based on ${ }^{210}$ Po measurements. Radiochem. Radioanal. Lett. 31, 207-214.

Lewis, E. L. \& Perkin, R. G. 1982: Seasonal mixing processes in an arctic fjord system. J. phys. Oceanogr. 12, 74-83.

Madsen, P. P. 1983: Sedimentakkumulationsrater i Arsuk Fjord. Unpublished report, 4 pp.

Møller, J. S. 1984: Hydrodynamics of an arctic fjord. Spec. Pap. Inst. Hydrodynam. Hydraul. Engng, Tech. Univ. Denmark 34, 73-124.

Pilegaard, K. 1983: Biological monitoring of airborne metal pollution around a lead-zinc mine in Greenland. Proc. int. Conf. Heavy Metals in the Environment, Heidelberg, 1133-1136. 